Tyndale Bulletin 67.2 (2016) 287-307

\title{
THE MASORA MAGNA OF TWO BIBLICAL FRAGMENTS FROM THE CAIRO GENIZAH, AND THE UNUSUAL PRACTICE OF THE SCRIBE BEHIND THE LENINGRAD CODEX
}

\author{
Kim Phillips \\ (k.1.phillips.00@cantab.net)
}

\begin{abstract}
Summary
As a rule, no two Tiberian Bibles are alike when it comes to their masoretic notes. Indeed, the masora magna notes can be thought of as part of the unique fingerprint of each individual manuscript. Notwithstanding, this study presents the first evidence of two Pentateuch codices containing identical masora magna, and explores how these codices relate to one another. Both these codices were the work of Samuel b. Jacob, the scribe who wrote the Leningrad Codex. Thus this study contributes to our understanding of the scribal habits of this important figure.
\end{abstract}

\section{Introduction: The Variety in the Masora Magna of Tiberian Masoretic Codices}

Prima facie, the model Tiberian Bible codices from the tenth and eleventh centuries are the epitome of uniformity and precision in textual transmission. Most obviously, the orthography preserves a textual tradition at least a millennium old - as witnessed by many of the non-Qumranic Dead Sea Scroll fragments. At a more synchronic level, the range of consonantal, vocalic, and accentual deviation among the best witnesses of the Tiberian masoretic tradition is - overall astonishingly minute.

On the other hand, the masoretic notes found in these codices show no such uniformity. At the visual level, this is true in terms of the 
layout of the masora magna (the longer notes found in the upper and lower margins of the Model Tiberian Bible codices). A cursory glance at the best known of these codices reveals a wide range of arrangements for the masora magna: from the rather sparse, austere notes above and below each of the three columns per page in the Aleppo Codex, to the densely written masoretic notes written in multiple long lines across the entire page, above and below the biblical text (and even in the outer margins of the page), in Or. 4445.

The variety in the masora of the Tiberian model codices is not limited to its layout. The content of the notes varies widely from codex to codex. Unlike the Babylonian tradition, the Tiberian masoretic tradition did not have a standardised text for the masoretic notes. ${ }^{1}$ Rather, each Masorete or scribe selected a subset of notes (perhaps according to interest and/or availability) from a vast pool of masoretic notes, with which to adorn his Bible codex. This applies equally to the masora parva (the brief, inter-columnar notes) as to the masora magna.

Yeivin discusses this lack of uniformity in the content of the masoretic notes of different codices:

The masoretic notes of Tiberian Bible manuscripts, though not normally contradicting one another, do not match one another. This applies even to manuscripts that are otherwise closely related in terms of period, and methods of pointing and accentuation. Notes that correspond thematically, do not always correspond in terms of language or wording. One manuscript comments on a particular word in a particular verse. Another only comments on a different word in that same verse. Even when the two manuscripts comment on the same word, the notes sometimes comment on different aspects thereof. Even with manuscripts as closely related as Aleppo, Leningrad and Cairo: in the majority of cases there is no correspondence between masoretic notes...

... Indeed, to date, no two Tiberian manuscripts have been uncovered whose masoretic notes correspond in all their details. ${ }^{2}$

This article contends, quite simply, that this claim is no longer quite accurate. Among the Bible fragments found in the Cairo Genizah, we now have, from a single codex, two folios whose masora magna agrees,

1 For an introduction to the Tiberian masoretic tradition, see Israel Yeivin, Introduction to the Tiberian Masorah, trans. and ed. E. J. Revell, The Society of Biblical Literature Masoretic Studies 5 (Missoula, MT: Scholars Press, 1980). For an introduction to the Babylonian masora, see Yosef Ofer, The Babylonian Masora of the Pentateuch: Its Principles and Methods, The Academy of the Hebrew Language: Sources and Studies VI - A New Series (Jerusalem: Magnes Press, 2001), 3-12.

2 Israel Yeivin, 'The Babylonian Masora to the Prophets', Eretz-Israel: Archaeological, Historical and Geographical Studies 16 (1982), 112. Italics added. 
in every detail, with the masora magna of another, well-known Bible codex. Our first task will be to introduce the fragments, and the Bible codex with whom they share this unique relationship. Thereafter, we will illustrate the identity of the masora magna of these two codices, against the backdrop of the equivalent masora magna of other prestigious biblical codices. Finally, we shall make some tentative steps towards ascertaining the nature of the relationship between these codices.

\section{The Manuscripts}

\subsection{T-S A2.46 and T-S A3.35}

At the end of the nineteenth century a vast collection of fragments of Jewish manuscripts was discovered in Fustat, in Old Cairo. The great majority of these fragments are now housed in Cambridge's University Library, forming the Taylor-Schechter Genizah Collection. The collection, consisting of approximately 200,000 fragments of manuscripts, from the ninth to the nineteenth centuries, contains approximately 20,000 fragments from Bible codices. Many of these biblical fragments are of relatively low quality: portions of the Bible copied for personal use, perhaps in the synagogue. However, a significant minority of the biblical fragments are from high quality model Tiberian Bible codices of equal prestige and antiquity to the well known codices such as the Leningrad Codex (L, written in AD 1008/9 by a scribe called Samuel b. Jacob).

T-S A2.46 and T-S A3.35 are two such fragments. ${ }^{3}$ The remnants of these leaves (containing material from Exod. 25-26 and Lev. 26-27 respectively) appear to derive from the same codex (henceforth referred to as the Genizah Codex): a codex that would have been truly impressive in its day. A complete page of this codex would have measured approximately $42 \mathrm{~cm}$ high, and $38 \mathrm{~cm}$ wide (as can be deduced from the measurements of T-S A2.46). The text is written (as with all such high quality Oriental codices) in three columns, on

3 Throughout this article, I use the Taylor-Schechter Genizah's determination of the verso and recto (reflected, for example, in the terminology used on the Friedberg Genizah Project website). It is important to note, however, that T-S A3.35 has been conserved the wrong way round: what is now the 'official' recto, is in fact the verso. 
vellum. In this codex each column measures approximately $25 \times 7 \mathrm{~cm}$, with seventeen lines per column. With an average letter height of nearly $1 \mathrm{~cm}$, written in a highly accomplished Oriental hand, and with wide margins around the three columns, containing two to four lines of masora magna in the upper and lower margins, this codex would have been an expensive production.

What proportion of the biblical text would the Genizah Codex originally have contained? The proportions above - and particularly the fact that there are only seventeen lines per column, suggest that the Genizah Codex originally contained only the Pentateuch. This can be inferred from the number of folios required. T-S A2.46 contains twenty verses on a single folio. To include all 5845 verses of the Pentateuch, therefore, nearly 300 such folios would be required. To give some sense of comparison, the well-known Pentateuch in the British Library collection, Or. 4445, contains the Pentateuch alone, on 186 folios, using twenty-one lines per column. The Damascus Pentateuch, using twenty lines per column, required 228 folios. By contrast, the Leningrad Codex contains the entire Hebrew Bible in 463 folios, but required twenty-seven lines per column to achieve this.

I have argued at length elsewhere that the codex from which T-S A2.46 and T-S A3.35 derive was written by none other than Samuel b. Jacob - the scribe who wrote the Leningrad Codex. ${ }^{4}$ This identification has a bearing on the final proposal of this article, though not the intervening steps of the argument.

\section{$2.2 L^{m}$}

This manuscript - a complete codex of the Torah - is rather better preserved than the few remaining fragments of the Genizah Codex. According to the extant colophon, this is yet another product of the calamus of Samuel b. Jacob, who wrote and vocalised it, and added the masoretic notes. ${ }^{5}$ This Torah manuscript is of unusual significance,

4 Kim Phillips, 'Two New Fragments from the Scribe behind the Leningrad Codex', in Research Approaches in Hebrew Bible Manuscript Studies. Proceedings of the EAJS LAB Conference, 6-8 June 2016, Aix-en-Provence, Studies in Jewish History and Culture (Leiden: Brill, 2017), forthcoming.

5 The relevant portion of the colophon reads: אני שמואל בן יעקוב כתבתי ונקדתי אני שמסרתי זה המצחף למרי ורבי דויד בן ישועה הלוי See Richard Gottheil, 'Some Hebrew Manuscripts in Cairo', JQR 17, no. 4 (1905), 629. B. Jacob claims, similarly, to have written, vocalised and added masoretic notes to his now-best-known Bible codex: the Leningrad Codex (see, e.g. the colophon on f. 474r). In this respect b. Jacob's practice is unusual: generally the model Tiberian codices were the product of at least two 
inasmuch as Samuel b. Jacob included in its masora magna a large number of notes from the Babylonian masoretic tradition. ${ }^{6}$ That is: many of the masoretic notes reflect the Babylonian text of the Bible, which differs in many small details from the text transmitted in the Tiberian tradition. By contrast, the biblical text itself in $\mathrm{L}^{\mathrm{m}}$ is a highly accurate reflection of the Tiberian Bible text. Thus, the manuscript contains a hybrid of traditions - traditions which clash in innumerable small details. It is not clear what precipitated b. Jacob's choice to merge the Tiberian and Babylonian traditions in this manner, or even whether he was aware of so doing. ${ }^{7}$ For the modern researcher, however, $\mathrm{L}^{\mathrm{m}}$ forms one of the most significant sources for the study of the Babylonian masora. Indeed, so significant is the masora magna of $\mathrm{L}^{\mathrm{m}}$ that a complete edition thereof (replete with many helpful explanatory notes) has been prepared by Breuer. ${ }^{8}$

No digital images are currently available of $\mathrm{L}^{\mathrm{m}}$. Nonetheless, various descriptions have been made. ${ }^{9}$ The codex, on vellum, measures $42 \mathrm{~cm}$ high by $38 \mathrm{~cm}$ wide. Each of the three columns per page comprises seventeen lines. The masora magna is written in three or four lines in the upper and lower margins of the page. Already, therefore, one can see that the dimensions and layout of $\mathrm{L}^{\mathrm{m}}$ and the Genizah Codex are identical. Our next task is to demonstrate the far more surprising result: that the masora magna is functionally identical in both manuscripts.

hands: the scribe would be responsible for the consonantal text and its layout, while the Naqdan would add the vowels, accents, and masoretic notes.

6 Ofer, Babylonian Masora, 15-25.

7 Ofer explains that the masora magna found in $\mathrm{L}^{\mathrm{m}}$ is predominantly a reworked, partially 'Tiberianised' version of the Babylonian masora (Babylonian Masora, 17-22). Ofer assumes that $b$. Jacob himself performed this reworking, as indeed seems most likely. Nonetheless, I see no reason, theoretically, why b. Jacob could not have simply received such a reworked masoretic composition, making use of which he then composed the masora magna of $\mathrm{L}^{\mathrm{m}}$.

8 Mordechai Breuer, ed., The Masorah Magna to the Pentateuch by Shemuel ben Ya'aqov (Ms. $L^{m}$ ), 2 vols., The Manfred and Anne Lehmann Foundation Series 16 (New York: Manfred and Anne Lehmann Foundation, 1992).

9 Gottheil, 'Hebrew Manuscripts', 629-630. Michèle Dukan, La Bible hébraïque: Les codices copiés en Orient et dans la zone séfarade avant 1280, Bibliologia: elementa AD librorum studia pertinentia 22 (Turnhout: Brepols, 2006), 320-322. 


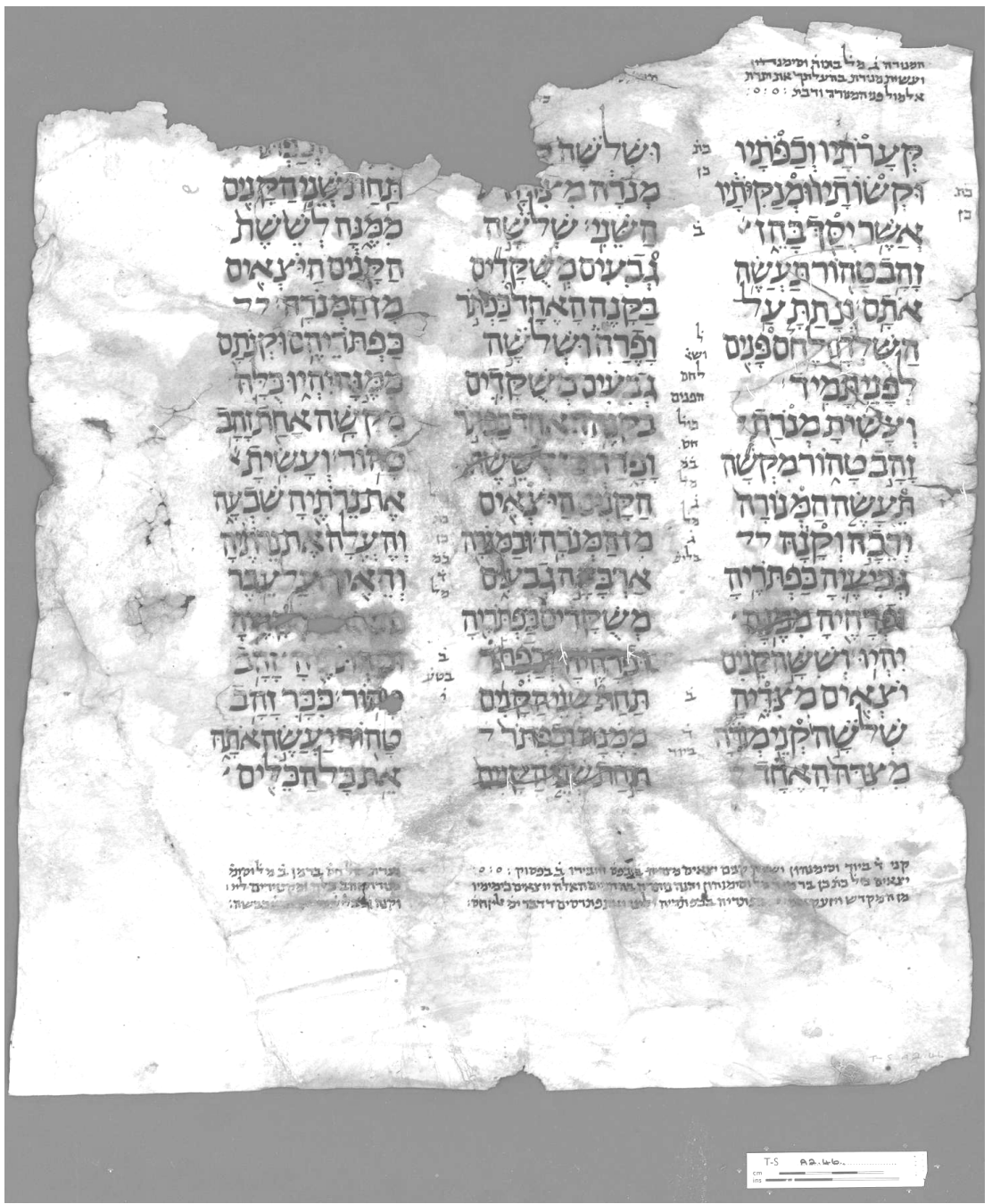

Figure 1: T-S A2.46r ${ }^{10}$

\section{The Masora Magna of T-S A2.46/A3.35 and that of $\mathbf{L}^{\mathbf{m}}$ are Identical}

This claim requires no special argument: it is immediately apparent to anyone who might take the trouble to look up the relevant manuscripts

10 Images reproduced by kind permission of the Syndics of Cambridge University Library. 


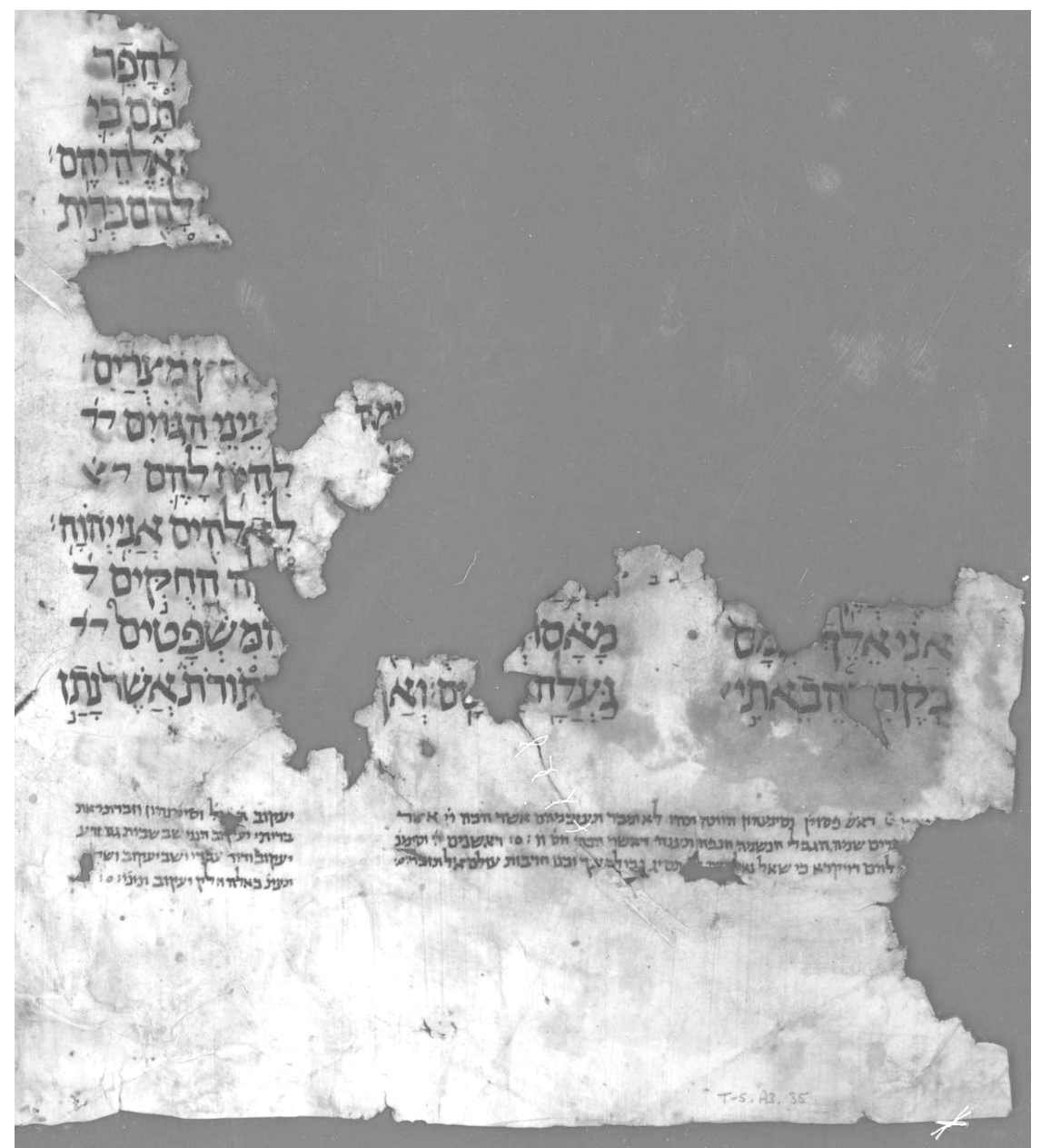

Figure 2: T-S A3.35v

for themselves. Nonetheless, because it is such a surprising claim (hitherto, one recalls, no two Tiberian Bible manuscripts have been found with identical masora magna), I will illustrate the identity in some detail, proceeding in two stages. First, it will be shown that, where it is possible to check, the same individual masora magna notes occur in both $\mathrm{L}^{\mathrm{m}}$ and T-S A2.46/A3.35, in the same order. Secondly, it will be shown that they occur with functionally identical wording unlike parallel notes from other codices of equal antiquity and prestige. 


\subsection{Identical Notes, Identical Order}

Before introducing the details of the masora magna of these manuscripts, it will be helpful to explain an idiosyncrasy in the manner in which Samuel b. Jacob customarily arranged the masora magna in his Bible codices. ${ }^{11}$

In a great many cases $b$. Jacob's masora magna $(m)$ surrounds the three columns of the biblical text $(\mathrm{X})$ thus:

\begin{tabular}{|c|c|c|}
\hline $\begin{array}{l}\text { mmmmmmmmmmm } \\
\text { mmmmmmmmmmm } \\
\text { mmmmmmmmmm }\end{array}$ & \multicolumn{2}{|c|}{$\begin{array}{l}\text { mmmmmmmmmmmmmmmmmmmmmmmmmm } \\
\text { mmmmmmmmmmmmmmmmmmmmmmmmmm } \\
\text { mmmmmmmmmmmmmmmmmmmmmmmm }\end{array}$} \\
\hline XXXXXXXXXXXX & XXXXXXXXXXXX & XXXXXXXXXXX \\
\hline XXXXXXXXXXXX & XXXXXXXXXXXX & XXXXXXXXXXX \\
\hline \multicolumn{2}{|c|}{ Mmmmmmmmmmmmmmmmmmmmmmmmmm } & mmmmmmmmmm \\
\hline \multicolumn{2}{|c|}{ Mmmmmmmmmmmmmmmmmmmmmmmmmm } & mmmmmmmmmm \\
\hline \multicolumn{2}{|c|}{ Mmmmmmmmmmmmmmmmmmmmmmmmmm } & mmmmmmmmmm \\
\hline
\end{tabular}

At the top, the masora magna is written continuously over the two first columns, and then over the third column in isolation $(2,1)$. This pattern is then reversed in the lower row of masora magna $(1,2)$. The mirror image of this layout is found on many other pages: $(1,2)$ at the top; $(2$, 1) at the bottom. Thus, his masora magna is written in four blocks on each page: two large, and two small. ${ }^{12}$

This layout is apparent on almost any page of the Leningrad Codex (b. Jacob's best known work). The same layout pertains in $\mathrm{L}^{\mathrm{m}} \cdot{ }^{13}$ Likewise, the masora magna of T-S A2.46 clearly follows this pattern. On the recto the distribution appears to be $(1,2)$ on the top, and is visibly $(2,1)$ on the bottom. ${ }^{14}$ A similar process of reasoning

11 Ofer, Babylonian Masora, 14. It is worth emphasising that, though this layout is characteristic of b. Jacob's work, it does not appear to be unique thereto. For example, JTS Lutzki 226 displays the same feature on several of its pages, as does CUL T-S A2.54r, yet these manuscripts do not show other traits typical of b. Jacob.

12 The layout of the masora magna surrounding pages with only two columns of biblical text is quite different, but need not concern us here.

13 Joseph Ofer, 'Review of: The Babylonian Masorah to the Pentateuch in a Tiberian Recension', Lešonenu 56 (1992), 270.

14 Though the great majority of the masora magna at the top of the second and third columns is lacking, one can reconstruct (on the basis of the extant text) the masoretic note being reproduced, the length of which dictates that this block must have extended 
demonstrates that the $\mathrm{Mm}$ on the verso has the pattern: $(1,2)$ top; $(2,1)$ bottom.

Due to the mutilated state of T-S A3.35, only the lower masora magna is visible. On both recto and verso the layout is $(2,1)$.

When one combines Samuel b. Jacob's habit of thus laying out the masora magna of his Bible codices with the additional fact that he assiduously avoids allowing any masoretic note to cross from one masora block to another, an important conclusion emerges. B. Jacob is forced to choose the masoretic notes he will include on any particular page, and the precise block of masora in which each note will appear, partly on the basis of length. ${ }^{15}$ Long masoretic notes (e.g. those listing many lemmata) could only be placed in the large masora blocks. The result is that the notes are rarely arranged in the same order as the biblical text. Moreover, a masoretic note is by no means guaranteed to occur in the margin closest to the relevant biblical text. ${ }^{16}$

Bearing the above considerations in mind, it seems most natural, when listing the masoretic notes on any given page, to proceed blockby-block: upper right, upper left, lower right, lower left. The results of such a procedure applied to T-S A2.46 are given in the left-hand column of the table below. The second column lists the masora magna notes of $\mathrm{L}^{\mathrm{m}}$ for the same stretch of biblical text contained in the lefthand column. The third column gives the same data from the Leningrad Codex (L); the fourth column from the Damascus Pentateuch (DP), and the final column from Or. $4445 .{ }^{17}$ In the case of L, DP and Or. 4445, I located the first occurrence of a masora magna note from the relevant text range (Exod. 25:29a-26:8b), and then included every note thereafter (whether from the relevant text range or not), until reaching the last note from the relevant text range. The only exception to this rule, in DP and Or. 4445, is where the scribe added collative masora. In this case, any data from the collative masora relevant to the text range

over both the second and third columns. For further details, see note (a) after Table 1 below.

15 Ofer, Babylonian Masora, 18.

16 Ofer, 'Review', 276n25 laments the fact that Breuer, in his edition of $\mathrm{L}^{\mathrm{m}}$, follows the incidental order of the masoretic notes as they appear in the manuscript, rather than rearranging them according to their biblical order. For our present purposes, however, Breuer's faithfulness to the order presented in the manuscript itself is serendipitous.

17 For brief introductions to these manuscripts, see Yeivin, Introduction, 18-21. Note that Yeivin discusses the manuscript we have labelled the Damascus Pentateuch in $\S 33$ on p. 21. The Aleppo Codex is, of course, not extant at this point, and therefore the equivalent data therefrom is not available for comparison. 
were included, but not the totality of the data, which would have meaninglessly enlarged the table to the point of absurdity.

Table 1: T-S A2.46 (Exod. 25:29a-26:8b)

\begin{tabular}{|c|c|c|c|c|}
\hline $\begin{array}{r}\text { Genizah } \\
\text { Codex }\end{array}$ & $\mathrm{L}^{\mathrm{m}}$ & $\mathrm{L}$ & DP & Or. 4445 \\
\hline $\begin{array}{r}\text { T-S } \\
\mathrm{A} 2.46 \mathrm{r}\end{array}$ & & $\underset{46 r+v^{18}}{F}$ & $\begin{array}{r}\text { Pp. } 155- \\
157^{19}\end{array}$ & $\begin{array}{r}\text { F. } 66 \mathrm{v}- \\
67 \mathrm{v}^{20}\end{array}$ \\
\hline המנורה & המנורה & המנורה & המנורה & \\
\hline 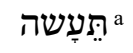 & תֵתֵֶשה & תֵתָששה & תַּעַשה & ונשא \\
\hline קני & קני & וראה & וכן תעשה & מנרת \\
\hline יצאים & יצאים & וראה d & ועשה & • עבר \\
\hline כפתריה & כפתריה & וכן תעשה & וראה & ואת המשכן \\
\hline מנרת & מנרת & תלעת & עאמהים & נוראה \\
\hline וקנהּ & וקנה & באמה & האֶָתת & האֶָת \\
\hline $\begin{array}{r}\mathrm{T}-\mathrm{S} \\
\mathrm{A} 2.46 \mathrm{v}\end{array}$ & & & & וכן תעשה \\
\hline$-\mathrm{b}$ & ככר זהב & & & כרבים \\
\hline c יעשה c & יעשה & & & \\
\hline יריעת & יריעת & & & \\
\hline האֵחת & האֵחת & & & \\
\hline וראה & וראה & & & \\
\hline עאמהים & עאמהים & & & \\
\hline תכלאת & ללאת תכל & & & \\
\hline
\end{tabular}

\footnotetext{
18 Exod. 25:29 begins halfway down the third column of f. 46r, and 26:8b ends at the top of the third column of f. $46 \mathrm{v}$.

19 Exod. 25:29 begins one third of the way down the middle column of p. 155 (using the pagination given by the pencil numbering on the manuscript itself), and $26: 8 \mathrm{~b}$ ends at the top of the first column on p. 157.

20 Exod. 25:29 begins halfway down the third column of f. 66v, and 26:8b ends at the top of the second column of f. $67 \mathrm{v}$.
} 


\section{Notes on Table 1}

a. This masoretic note is all but missing in T-S A2.46 due to the oblique tear at the top of the leaf. Nonetheless, just over two words are yet visible: תינינ' של at the beginning of the second line, and at the beginning of the third line. Moreover, the third line is clearly a centre-justified final part-line. ${ }^{21}$ According to the order of the masoretic notes found in $\mathrm{L}^{\mathrm{m}}$, the note that should occupy this block concerns the Niphal Imperfect תעשה. Sure enough, on the basis of the average number of letters per line of masora in T-S A2.46, this note fits perfectly in the available space, and matches the extant words precisely.

b. Due to the oblique tear at the top of T-S A2.46, the first block of masora (a small block) is entirely missing. According to the ככר זהב equivalent note in $\mathrm{L}^{\mathrm{m}}$, this block should contain a note on (Exod. 25:39). Sure enough, on the basis of the average number of letters per line, the note would fit neatly into a two line masoretic block.

c. Only the latter four words of this eleven word note are extant in T-S A2.46. The remainder of the note (as reconstructed according to its parallel in $\mathrm{L}^{\mathrm{m}}$ ) fits precisely into the available space of the masora block.

d. This masoretic note has been duplicated in L, on the same page: once in an upper masoretic block, and once in a lower block.

The table above strikingly illustrates the close relationship between the masora magna notes found in T-S A2.46 and those of $\mathrm{L}^{\mathrm{m}}$. The two codices contain the same set of fourteen notes, in the same order. ${ }^{22}$ When one compares this with the same stretch of data from $\mathrm{L}$ - also written by Samuel b. Jacob - and the other two early codices, the results are noteworthy. There is no comparable identity of notes. Indeed, the closest other manuscript to T-S A2.46 and $\mathrm{L}^{\mathrm{m}}$ is DP, which includes five of the fourteen notes, with general agreement in the order of occurrence. Clearly, in terms of choice of notes, and order of arrangement, there is a very particular relationship between T-S A2.46 and $\mathrm{L}^{\mathrm{m}}$ that is not shared among any other pairing of the five manuscripts represented in the table above.

21 It is Samuel b. Jacob's custom, for masoretic notes of three lines or more, to centrejustify final part-lines. Examination of any page of the Leningrad Codex exemplifies this.

22 Or thirteen notes, if one wishes to exclude ככר זהב (Exod. 25:39). 
The evidence above has been drawn exclusively from A2.46, due to the more complete nature of the folio. Precisely the same approach could have been taken, however, with A3.35. In that fragment, the same set of five masora magna notes appear as in the equivalent stretch of text in $\mathrm{L}^{\mathrm{m}}$.

Is it possible that this identity between the selection and order of the masoretic notes in T-S A2.46/A3.35 and $\mathrm{L}^{\mathrm{m}}$ arose purely by chance? It is possible, of course, but overwhelmingly implausible. A simple, and grossly approximate, calculation, will exemplify this implausibility. We have seen that T-S A2.46 has the same fourteen notes, in the same order, as found in the equivalent portion of $\mathrm{L}^{\mathrm{m}}$. The other three manuscripts sampled together yield a further nine notes, not found in $\mathrm{T}-\mathrm{S} \mathrm{A} 2.46 / \mathrm{L}^{\mathrm{m}}$. If we suppose (grossly underestimating, no doubt), that this total of twenty-three notes represents the entire pool of masoretic notes available for this stretch of the biblical text, we can calculate the probability of T-S A2.46 and $\mathrm{L}^{\mathrm{m}}$ independently arriving at the identical selection of the same fourteen notes, in the same order, as $9 ! / 23 !=$ $1 /\left(7.1 \times 10^{16}\right)$, a probability so small that the first two calculators with which I performed the calculation simply returned the result: 0 . Doubtless, this calculation is so crude as to be laughable. Nonetheless, it illustrates just how vanishingly small is the probability that these two manuscripts arrived at their identical masora magna purely by chance. There must be some sort of genetic relationship between the two manuscripts.

\subsection{Identical Wording of the Notes}

It remains to demonstrate that the masoretic notes of T-S A2.46/A3.35 and those of $\mathrm{L}^{\mathrm{m}}$ are functionally identical in wording, unlike the equivalent notes in the other codices. This functional identity is most simply illustrated by means of an example. In the table below we will compare the masoretic note concerning the phrase וּרְ (Exod. 25:40). This note has been chosen for the fact that it contains, within the space of one relatively short comment, a variety of the typical types of divergences found between the wording of T-S A2.46/A3.35 and that of $\mathrm{L}^{\mathrm{m}}$. A corresponding disadvantage, however, is that this note contains an unrepresentatively high degree of divergence between the two sets of notes: 
וראה ג' ראשי פסוק' וראה ועשה וראה וראה ג' ראש' פסוק' וראה ועשה

וראה אם דרך וראה בנים לב'23' וראי וראי אם דרך עצב בי וראה בנים לבני וראה ועשר ורני

It will be seen from the above that the two notes are very similar indeed; only three small deviations are apparent. In each case, T-S A2.46 has the shorter text. ראשי has been shortened to the abbreviation 'ראש; likewise, לבניך has been shortened to the

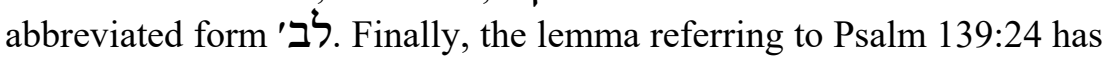
been shortened, excising the words עצב בי. An examination of the manuscript itself immediately reveals that the latter two contractions are due to b. Jacob's attempt to fit the entire masoretic note into less than a single line of masora.

The great majority of the deviations between the masora magna of T-S A2.46/A3.35 and that of $\mathrm{L}^{\mathrm{m}}$ consists of these sorts of contractions - particularly different ways of abbreviating the well known masoretic terminology. Moreover, the contractions are spread among both manuscripts - it is not the case that T-S A2.46/A3.35 always contains the shorter text, as one might have falsely inferred from the example above. Such deviations are clearly not 'substantive' differences between the notes; functionally, the notes are identical.

The same cannot always be said for the relationship between the wording of shared notes in the other codices. Again, this will simply be illustrated by an example. The only note common to all five codices is that which considers the phrase וּרְ (Exod. 25:40). However, as the evidence from this note is considered in a slightly different connection below, the note on הָזָז (Exod. 26:5) is considered instead:

\begin{tabular}{|c|c|c|c|}
\hline T-S A2.46 & $\mathbf{L}^{\mathbf{m}}$ & DP & Or. 4445 \\
\hline האחת ג' & האחת ג' & האחת ג' & האחת ג' קמצין \\
\hline וסימנהון & וסימנהון & וסימנהון & וסימנהון \\
\hline חמשים ללאת & חמשים ללאת & חמשים ללאת & חמשים \\
\hline וחביר' & וחבירו & וחבירו & חמשים \\
\hline צל השבכה הל & על השבכה האחר & השבכה האחת॰ & - \\
\hline
\end{tabular}

23 This masoretic note simply records the three verses in the Hebrew Bible that begin with the imperative :iּn : Exod. 25:40; Pss. 128:6; 139:24. 


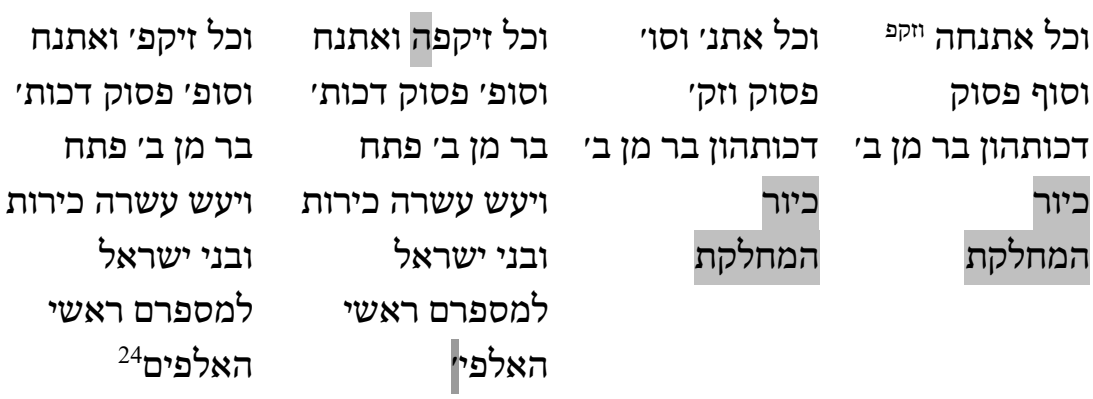

It is apparent from the layout above that, despite the fact that the note in each manuscript is making the same point, the wording in T-S A2.46 is substantially closer to the wording in $\mathrm{L}^{\mathrm{m}}$ than to the wording in either DP or Or. 4445. As expected, the divergences between T-S $\mathrm{A} 2.46$ and $\mathrm{L}^{\mathrm{m}}$ are restricted to issues of word contraction. By contrast, in some cases DP and Or. 4445 cite totally different lemmata (though referring to the same verses), and also show additional differences in word order.

The identical wording of the masora magna notes between T-S $\mathrm{A} 2.46 / \mathrm{A} 3.35$ and $\mathrm{L}^{\mathrm{m}}$ includes within it two rather distinguishing features, which further illustrate the claim that there must be some sort of genetic relationship between $\mathrm{L}^{\mathrm{m}}$ and the Genizah Codex (at least for these portions of text). Namely: both manuscripts' masora show the influence of the Babylonian biblical tradition, and both contain the same citation errors.

\section{a. The Underlying Babylonian Tradition}

One of the large-scale differences between the Babylonian biblical tradition versus the Tiberian, is the different order of some of the biblical books. The Babylonian order is recorded in the talmudic tractate b.Bava Bathra 14b. Of particular significance is the fact that, in this tradition, Isaiah is placed after Ezekiel, thus giving the order: Jeremiah, Ezekiel, Isaiah for the major prophets, rather than the Tiberian order of Isaiah, Jeremiah, Ezekiel. Similarly, the position of Chronicles differs between the traditions. In the Tiberian tradition Chronicles opens the Ketuvim - the third section of the scriptures, whereas in the Babylonian tradition Chronicles closes the Ketuvim (and hence the entire Hebrew Bible). How does this manifest itself in the masora magna? When any particular masoretic note wishes to refer

24 This note discusses the occurrences of the word 
to a particular word or phenomenon occurring in multiple biblical texts, it usually lists the pertinent texts (using short lemmata) in their scriptural order. ${ }^{25}$ If, therefore, lemmata are listed from Isaiah, followed by lemmata from Ezekiel, this would be evidence of the Tiberian tradition. If, however, lemmata were listed from Ezekiel, followed by lemmata from Isaiah, this would be evidence of the Babylonian tradition.

It must be remembered, of course, that by no means every list of lemmata will reveal either a Tiberian or Babylonian basis, as the order of the great majority of the biblical books is identical between both traditions. For example, a list of lemmata with the order: Genesis, Numbers, Deuteronomy, Samuel, Ezekiel, Hosea, Chronicles could be of either Tiberian or Babylonian origin. This tool cannot by any means be applied to every masoretic note.

Nonetheless, this Babylonian ordering of the scriptural lemmata is perceptible in two of the masoretic notes in the extant remains of the Genizah Codex - with, of course, their twins in $\mathrm{L}^{\mathrm{m}}$ itself. On T-S A2.46v, the masora magna note on יריעת (Exod. 26:1) cites lemmata from Isaiah, Habakkuk, Song of Songs and Chronicles. The order of the latter two books suggests Babylonian origin. Similarly, on T-S

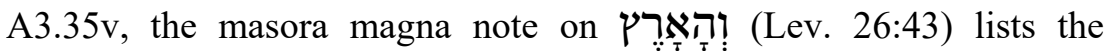
lemmata from the major prophets in the order: Ezekiel, Isaiah, again reflecting the Babylonian tradition.

\section{b. Shared Citation Errors}

Yet further proof of the claim that the masoras of T-S A2.46/A3.35 and $\mathrm{L}^{\mathrm{m}}$ must be genetically related is found in the fact that they even share the same citation errors:

1. On T-S A2.46v the masora magna records a note on the word

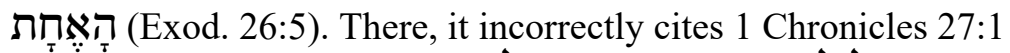

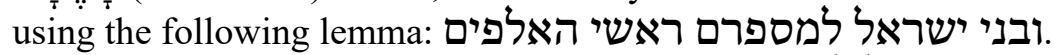

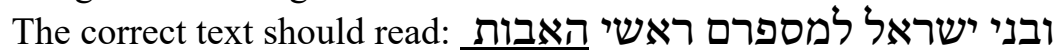
.ושרי האלפים.

2. Also on T-S A2.46v the masora magna records a note on the word (וּרְ (Exod. 25:40). There, lemmata are cited from Exodus 25, Psalm 139, and Psalm 128. The citations from the Psalms are in the

25 Breuer, $L^{m}, \mathrm{xx}$.

26 See, Breuer, $L^{m}, 370$. 
wrong order in both T-S A2.46 and $\mathrm{L}^{\mathrm{m}}$. In L, DP and Or. 4445, however, the Psalms are presented in their canonical order.

3. On T-S A3.35v, the masora magna records a note on the word

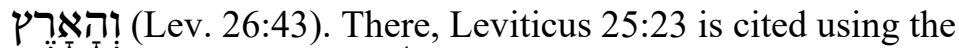
incorrect lemma: לא ימכר : לאר : The correct lemma ought to read תמכר. ${ }^{27}$

4. On T-S A3.35r the masora magna records a note on the word וִ (Lev. 27:9). There, Obadiah 1:4 is cited using the incorrect lemma: ואם בן. The correct lemma ought to read: ואם ביואין.

\subsection{Summary}

The above evidence clearly illustrates the identical nature of the masora magna found in T-S A2.46/A3.35 to that found in $\mathrm{L}^{\mathrm{m}}$. Moreover, I hope to have demonstrated beyond doubt that the masoretic material found in T-S A2.46/A3.35 must be genetically related to the twin material found in $\mathrm{L}^{\mathrm{m}}$. It is utterly implausible that the identity of material arose by chance. The identical selection and ordering of the notes proves the point; the functionally identical wording - even sharing the same Babylonian influence and the same citation errors proves it equally. It remains, therefore, to enquire what broader conclusions this evidence might point to.

\section{The Nature of the Relationship between the Genizah Codex and $\mathbf{L}^{\mathrm{m}}$}

Two fragmentary folios do not make a codex. That is to say: any broader conclusions drawn on the basis of the limited evidence available in T-S A2.46/A3.35 must necessarily be tentative. It may be, for example, that these two leaves were originally intended for inclusion in what is now $\mathrm{L}^{\mathrm{m}}$ itself. Perhaps the other halves of the bifolia of which they were once part contained errors so egregious that the entire sheet had to be re-written. Alternatively, it is possible that these fragments did originally come from a complete Pentateuch codex, but that the masora magna found on these fragments is not representative of the nature of the masora magna of the rest of the codex.

27 See, Breuer, $L^{m}, 535$.

28 See, Breuer, $L^{m}, 536$. 
Such scenarios are certainly possible. If we grant, however, that there really was once a complete Genizah Codex (and the external evidence below may support such a conclusion), and that the nature of its masora magna is accurately reflected in the fragments analysed above, this raises the pressing question: How did it come to pass that two Pentateuch codices (the Genizah Codex, and $\mathrm{L}^{\mathrm{m}}$ ) contain identical masora magna? As noted in the introduction, no two other codices have yet been found with identical masora magna.

At the risk of oversimplifying the matter, it seems to me that the two codices could be related either as twin sisters, or as parent and daughter. Let us consider each in turn.

\section{1 $L^{m}$ and the Genizah Codex May be Twin Sisters}

On this understanding, the masora magna of both codices would have been copied from a shared source. This source may have been a third Bible manuscript, or a separate document containing the masora magna as a distinct text. Further reflection suggests that the third source is unlikely to have been a Bible manuscript. In such a manuscript, the masora magna would have been arranged in its own idiosyncratic order. Let us suppose, arbitrarily, that $\mathrm{L}^{\mathrm{m}}$ was written before the Genizah Codex. Thus, when Samuel b. Jacob came to write $\mathrm{L}^{\mathrm{m}}$, he would have selected the masoretic notes he required from those contained in the third manuscript, rearranging them to suit the requirements of the layout of $\mathrm{L}^{\mathrm{m}}$. Later (unless one adds the further hypothesis that $\mathrm{L}^{\mathrm{m}}$ and the Genizah Codex were written at the same time), when b. Jacob came to write the Genizah Codex, again using the third text as his source, are we to suppose that he happened to remember exactly the set of notes he had gleaned from the third manuscript, and the order in which he wrote them in $\mathrm{L}^{\mathrm{m}}$ ? This seems implausible. Alternatively, one might argue that b. Jacob copied all the notes from the third manuscript into $\mathrm{L}^{\mathrm{m}}$, in the same order, and then repeated this procedure when later copying the Genizah Codex. However, this would imply three manuscripts with identical masora magna in each, rather than two. The explanation below (that $\mathrm{L}^{\mathrm{m}}$ and the Genizah Codex are related as parent and daughter) is able to explain all the relevant data without the need to suppose the existence of a third manuscript with identical masora, and is therefore preferable to this hypothesis. 
Perhaps, though, the third source was a separate document containing the masora magna as a distinct text. Such a scenario could explain the identical selection of notes, in the same order, with the same errors. Moreover, it is well known that the Babylonian Masora of the Pentateuch (with which, as discussed in the Introduction, the masora magna of $\mathrm{L}^{\mathrm{m}}$ has a very close affinity) was transmitted not primarily in the margins of Bible codices, but as a separate text. However, again a difficulty emerges. It is, for the same reasons adduced in the previous paragraph, necessary on this hypothesis to assume that $b$. Jacob copied out the entirety of the masora magna found in the separate document when writing $\mathrm{L}^{\mathrm{m}}$. For, if he limited himself to a subset of the contents, one has to then assume that when later writing the Genizah Codex, he remembered precisely the subset of notes he had previously copied into the margins of $\mathrm{L}^{\mathrm{m}}$. If, then, we assume that b. Jacob did indeed copy out the entire masora magna found in the third source, we encounter the remarkable, Goldilocks-esqe coincidence that those notes fitted perfectly into his rather strictly delimited masora magna blocks. The masoretic material found in the third source was not too big for the margins of $\mathrm{L}^{\mathrm{m}}$, nor too small, but just right. Again, this seems implausible.

\subsection{The Two Codices are most likely to be Parent-Daughter}

It seems to me most plausible that $\mathrm{L}^{\mathrm{m}}$ and the Genizah Codex are genetically related as Parent-Daughter: i.e., one of these manuscripts was written first, with the masora magna written specifically to fit that manuscript's particular layout. Subsequently, the later manuscript was written as an attempt to be a carbon copy of the former. Such a hypothesis fits the internal evidence of the manuscripts. It was noted in the introduction that the layout and size of $\mathrm{L}^{\mathrm{m}}$ and the Genizah Codex are the same: $42 \times 38 \mathrm{~cm}$, three columns per page, each with seventeen lines. This evidence, combined with the identical masora, is consistent with the notion that the later manuscript was an attempt to be a carbon copy of the earlier.

More significantly, the genizah provides interesting external support for the idea that the two codices could be linked as parent and daughter. The evidence comes from fragment T-S 10J5.15: 


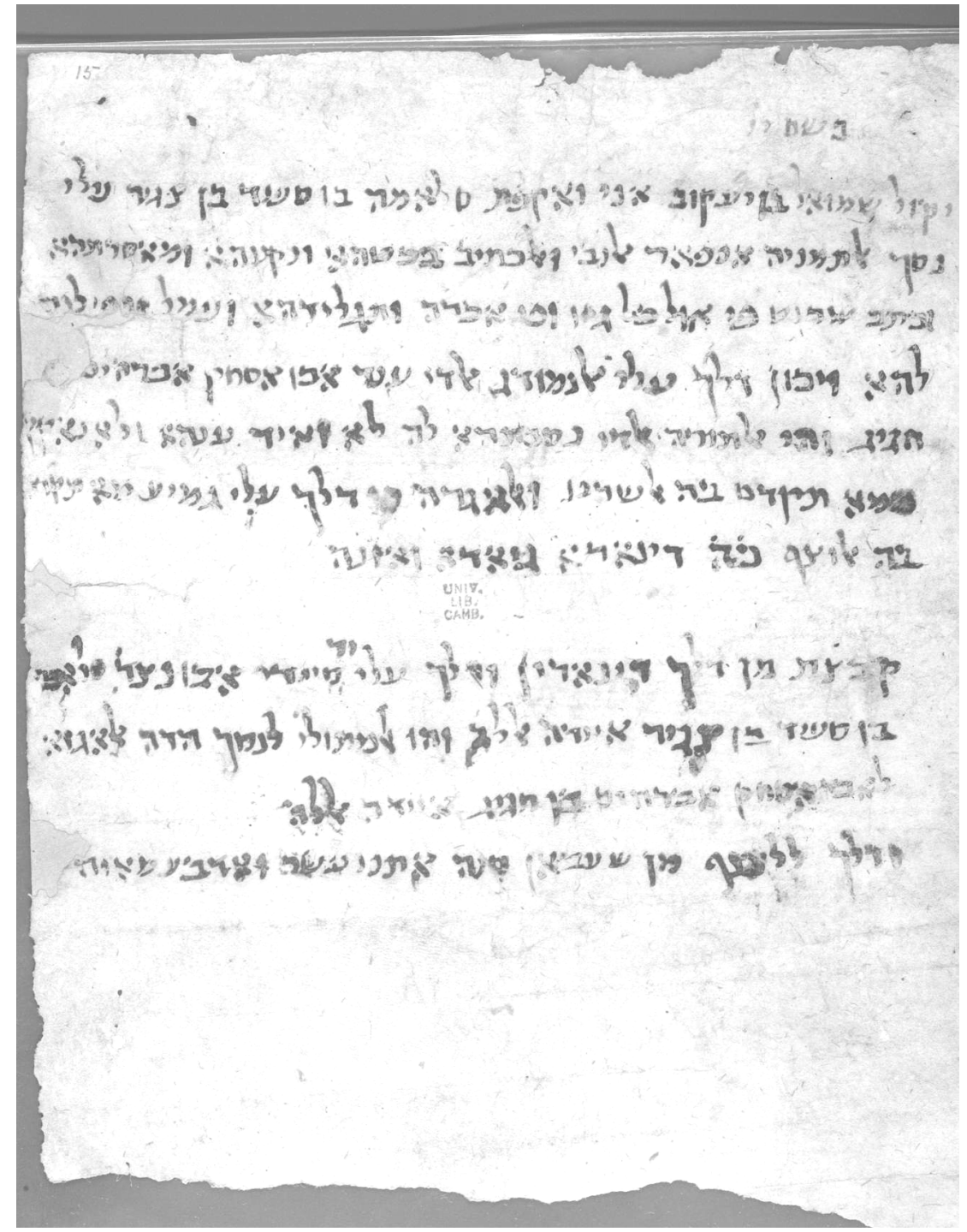

\section{Figure 3: T-S 10J5.15}

This Judaeo-Arabic legal document deals with none other than Samuel b. Jacob (whose name appears in the first line of the text), the scribe who wrote the Leningrad Codex, $\mathrm{L}^{\mathrm{m}}$, and - I have claimed - the Genizah Codex as well. In this document b. Jacob agrees to copy eight books of the Prophets and Writings. Significantly, he agrees to copy 
the text from an exemplar of his own production, currently in the possession of a well known figure, Abraham b. Haggai. ${ }^{29}$

In the case of this copy of the Prophets and Writings we do not know whether $b$. Jacob aspired to make a carbon copy of the exemplar. This document does, however, provide clear evidence that b. Jacob, on at least one occasion, made a second copy of a Bible, using an exemplar which was itself his own work. This, of course, is what is being claimed in the case of $\mathrm{L}^{\mathrm{m}}$ and the Genizah Codex.

Naturally, positing a parent-daughter relationship between these manuscripts immediately raises the question of which manuscript derives from which. Here, humblingly, the trail peters out. The minute deviations in wording between the masora of the different codices does not, at least to my mind, point definitively in either direction. It is dearly to be hoped that a) electronic images of $\mathrm{L}^{\mathrm{m}}$ will be made available soon; and b) further fragments from the Genizah Codex will be identified among the various repositories of mediaeval Hebrew Bible manuscripts throughout the world.

\section{Conclusion}

The scribal habits of Samuel b. Jacob are of uncommon significance to students of the Hebrew Bible. One of his productions - the Leningrad Codex - remains the earliest complete Hebrew Bible in existence. For many, this manuscript (often in the form of BHS) is the Masoretic Text, however much scholars of the mediaeval Hebrew Bible shudder at such an identification. Samuel b. Jacob's oeuvre, therefore, has immense de facto significance. Understanding more about that oeuvre, therefore, and its position relative to the wider practices of Jewish biblical scribery in the early post-masoretic period, is a desideratum. The 'star-turn' of this article, is of course the claim that we now have evidence (contrary to all previous evidence) of two Bible codices containing identical masora magna. Beyond this, though, the evidence above presents one, small, further brush stroke towards this larger picture. I have suggested that (assuming T-S A2.46/A3.35 really do

29 Ben Outhwaite, 'Samuel ben Jacob: the Leningrad Codex B19a and T-S 10J5.15', Cambridge University Library Fragment of the Month (January 2016), http://www.lib.cam.ac.uk/collections/departments/taylor-schechter-genizah-researchunit/fragment-month/fragment-month-janua- 0 . 
come from a once-complete codex: the Genizah Codex) the twin manuscripts $\mathrm{L}^{\mathrm{m}}$ and the Genizah Codex are related in a parent-daughter relationship: one was copied directly, and identically, from the other. The Cairo Genizah affords independent evidence that $\mathrm{b}$. Jacob, on at least one other occasion, copied a Bible from an exemplar that was also his own production. The fact that these manuscripts with identical masora magna are apparently the first to have been found, suggests that such cloning of manuscripts was not a common occurrence. If so, then this must be added to the growing list of the unusual practices of Samuel b. Jacob. 
